\title{
Oxidant and antioxidant status in children with juvenile idiopathic athritis
}

\author{
Hakan M Poyrazoglu, Ikbal Gökçek, Cevat Yazici, Ruhan Düsünsel”, Zübeyde Gündüz, Ismail Dursun \\ From 18th Pediatric Rheumatology European Society (PReS) Congress \\ Bruges, Belgium. 14-18 September 2011
}

\section{Background}

Although the pathogenesis of juvenile idiopathic arthritis is poorly understood, it is thought that a triggered inflammation by neutrophil activation due to any reason, released free oxygen radicals and insufficiency of antioxidant system may play role in the chronic course of this disease.

\section{Aim}

In present study, it was aimed to identify the status of oxidant-antioxidant systems.

\section{Methods}

In this study, 45 patients with JIA were included. In patients with active disease and in remission, erythrocyte sedimentation rate (ESR), C-reactive protein (CRP), Advanced Oxidation Protein Products (AOPP), myeloperoxidase (MPO), thiol, Total Anti-oxidant capacity (TAC), Total Oxidant Capacity (TOC) and neopterin levels were measured.

\section{Results}

Mean age of patients was 9.6 years. Female: male ratio was $1.5(\mathrm{~F} / \mathrm{M}=27 / 18)$. Oligoarticular JIA was diagnosed in 21 patients, whereas polyarticular JIA and systemic JIA in 17 and in seven patients, respectively. During study period, 23 patients had active disease, while 22 patients were in remission. Mean duration of disease was 2.2 years.

Serum ESR, CRP, TOC, TAC and, MPO levels were found higher in the patients with active disease than those in remission $(\mathrm{p}<0.05)$. No difference was found in neopterin, AOPP and thiol levels.

Erciyes University Medical Faculty, KAYSERI, Turkey

\section{Conclusion}

The results of the present study indicate that oxidantantioxidant systems are active in JIA patients during active phase. This activation in favor of oxidants is interesting. More comprehensive studies are needed to determine whether this is cause or result.

Published: 14 September 2011

doi:10.1186/1546-0096-9-S1-P296

Cite this article as: Poyrazoglu et al:: Oxidant and antioxidant status in children with juvenile idiopathic athritis. Pediatric Rheumatology 20119 (Suppl 1):P296.
Submit your next manuscript to BioMed Central and take full advantage of:

- Convenient online submission

- Thorough peer review

- No space constraints or color figure charges

- Immediate publication on acceptance

- Inclusion in PubMed, CAS, Scopus and Google Scholar

- Research which is freely available for redistribution
C Biomed Central

\section{Biomed Central}

